\title{
Emergence and seedling survival of caldén in the semiarid region of Argentina
}

\author{
DANIEL V. PELÁEZ, ROBERTO M. BÓO, AND OMAR R. ELIA
}

\begin{abstract}
Authors are professor and researcher, Departamento de Agronomia (UNS) and Comision de Investigaciones Cientificas de la Provincia de Buenos Aires; professor and researcher, Departamento de Agronomia (UNS) and Comisión de Investigaciones Cientificas de la Provincia de Buenos Atres; Research Technician, Centro de Recursos Naturales Renovables de la Zona Semiárida; Departamento de Agronomia, Universidad Nacional del Sur, 8000 Bah $/ 8$ a Blanca, Argentina.
\end{abstract}

\begin{abstract}
Calden (Prosopis caldenia Burk.) is one of the woody species that is increasing in abundance due to poor grazing management in the semiarid region of central Argentina. The objectives of this work were to evaluate emergence and seedling survival of caldén under grazed-low herbaceous foliar cover, and ungrazed-intermediate and ungrazed-high herbaceous foliar cover. Seedling emergence was recorded weekly after 3 planting dates: October 1987, September 1988, and October 1989. Seedling survival was recorded every 2 weeks until all seedlings died. Precipitation, soil water potential, and soil temperature were monitored during the study period. Since caldén only reproduces from seeds, optimal conditions for germination under different controlled photoperiod and temperature regimes were also studied. In the laboratory, greatest germination of freshly harvested unscarified seeds occurred at a diurnally alternating temperature regime of 15 and $30^{\circ} \mathrm{C}$ with light provided for 9 hours. Least germination occurred at $15^{\circ} \mathrm{C}$ and continuous darkness. Acid scarification significantly increased germination percentage and germination rate. Unscarified seeds incubated in light exhibited a lower rate of germination than scarified seeds under all temperatures. In the field, soil water availability was usually similar among the 3 experimental conditions. Soil temperature was only occasionally higher in the grazedlow herbaceous cover site. Only for 1987 data, emergence was greater on the grazed area with relatively low herbaceous foliar cover and similar within the ungrazed area. Treatment effect was very little on seedling survival, being lower in the grazed area for only 2 evaluation dates in 1989. Regardless of treatment the emerged seedlings survived $\mathbf{4 0}$ days on the average. The highest caldén seedling mortality was always coincident with higher soil temperature and lower soil water availability.
\end{abstract}

Key Words: germination, soil environmental factors, Prosopis caldenia Burk., woody plant invasion

According to Vallentine (1974) grazing by domestic livestock is one of the primary causes for invasion of rangelands by woody plants. Jacoby (1986) pointed out that overgrazing, with its direct or indirect effects, has allowed and encouraged increasing densities of native shrubs in semiarid rangelands. However, results from several studies on the importance of the relationship between grazing, herbaceous biomass and woody plant invasion do not agree (Smith and Schmutz 1975, Young et al. 1981, Walker et al. 1981, Meyer and Bovey 1982).

Continuous grazing with excessive stocking rates has occurred for many decades in the semiarid phytogeographic region of central Argentina known as the Caldén District (Cabrera 1976), commonly referred to as the Caldenal. This may have contributed to

Manuscript accepted 15 Mar. 1992. the increased abundance of woody vegetation evident across the region. The decrease in the herbaceous cover due to overgrazing may have produced microenvironmental changes, which in turn may have created suitable sites for emergence and seedling survival of woody plants. The nature of the environment immediately surrounding a seedling and its effects on that seedling are of critical importance in determining the dynamics of plant populations and the composition of plant communities (Fowler 1988).

Our objectives were to document the effect of varying herbaceous foliar cover, as related to grazing, on emergence and survival of calden (Prosopis caldenia Burk.) seedlings, one of the dominant woody species in the Caldenal, and on selected microenvironmental factors which may be important in seedling establishment. Because caldén only reproduces from seeds, optimal conditions for germination were also studied in the laboratory.

\section{Study Area}

The study was conducted in a 9-ha exclosure that had been fenced 6 years earlier, and in an adjacent continuously grazed area. The site is in southeast La Pampa province $\left(38^{\circ} 45^{\prime} \mathrm{S}\right.$ lat. and $63^{\circ}$ 45' W long.).

The vegetation on the study site is typical for the region. It has a shrub layer of variable density with caldén, algarrobo (Prosopis flexuosa DC.), piquillin (Condalia microphylla Cav.), and jarilla Larrea divaricata Cav.). The herbaceous layer is highly productive with flechilla negra (Piptochaetium napostaense (Speg.) Hackel) and flechilla fina (Stipa tenuis Phil.) as the most abundant species. These 2 grasses account for $\mathbf{7 5 \%}$ of the total perennial herbaceous foliar cover (Distel and Fernández 1987). Other common grasses at the study site include coirón (Stipa speciosa Trin. et Rupr.), poa (Poa liqularis Ness.) and cola de zorro (Pappophorum mucronulatum Ness.).

Average annual temperature is $15^{\circ} \mathrm{C}$. Annual precipitation averages $344 \pm 98 \mathrm{~mm}$, concentrated mainly in spring and fall, and the annual water deficit is about $\mathbf{4 0 0} \mathbf{~ m m}$ (INTA 1980).

Soil is a typical Paleorthid, well drained, with a medium to heavy texture and a slope of 0.5 to $1 \%$. A petrocalcic horizon ("tosca") is present at a depth of 40 to $60 \mathrm{~cm}$.

\section{Materials and Methods}

\section{Germination}

Calden pods were collected within the study area in March of 1987 and maintained under laboratory conditions $\left(18\right.$ to $25^{\circ} \mathrm{C}$ ). Seeds were manually removed from the pods and incubated in controlled-temperature chambers. For each treatment 4 replicates of 30 seeds per replicate were used. Seeds were treated with Carboxin-Thiram $0.2 \%$ to inhibit fungal infections, placed on filter paper in transparent plastic boxes ( 5.5 by 7.5 by $1 \mathrm{~cm}$ ) and kept 
moist with distilled water. An open beaker of water was kept inside the chamber to maintain a high relative humidity. Seeds were incubated at continuous temperatures of 15,20 , and $25^{\circ} \mathrm{C}$ and at 2 diurnally alternating regimes, $15^{\circ} \mathrm{C}$ for 15 hours and 25 or $30^{\circ} \mathrm{C}$ for 9 hours. Germination was determined in each temperature treatment with light provided for 9 hours daily and in continuous darkness. Light was supplied with both fluorescent tubes and incandescent light bulbs. In alternating temperature regimes the light was provided during the high temperature regime. In the treatments that were exposed to continuous darkness, the boxes were wrapped with paper and a piece of black cloth. Germination of acid-scarified and unscarified seeds was compared in all temperature and light regimes. Acid-scarified seeds were soaked in concentrated sulfuric acid for $45 \mathrm{~min}$, then washed with distilled water until a neutral reaction was detected.

Germination was considered to have occurred when the radicles emerged. In the treatments under light regimes the number of emerged seeds was recorded at 72-hour intervals over the 30-day exposure period. In the treatments under continuous darkness, germination was recorded at the end of the exposure period.

Germination data were subjected to arc sine transformation. For each light-temperature treatment combination, scarified vs. unscarified seed germination means were compared as independent samples (Snedecor and Cochran 1980). An analysis of variance was performed on each set of transformed data (scarified and unscarified seeds) following a completely random design, differences among treatment means were separated with Duncan's multiple range test (Snedecor and Cochran 1980). Germination rate of seeds incubated in light was calculated with Maguire's equation (Maguire 1962):

number of germinated seeds $+\cdots \cdots+$ number of germinated seeds

$$
\text { days to first count days to final count }
$$

An analysis of variance was performed on these data following a completely random design. Differences among treatment means were separated with Duncan's multiple range test.

\section{Emergence and Survival}

Seeds from calden pods collected within the study site in March of 1987,1988 , and 1989 were scarified with sulfuric acid as described above and used in the emergence and seedling survival experiment. Three experimental sites were selected for this trial: grazed vegetation with relatively low herbaceous cover, and adjacent ungrazed vegetation with intermediate and higher herbaceous foliar cover. Two $20-\mathrm{m}$ permanent transects were placed in each experimental area. One seed was planted every $25 \mathrm{~cm}$ along the transects at a depth of $1 \mathrm{~cm}$ in October 1987, September 1988, and October 1989. Emergence (seedlings/number of seeds planted) was recorded weekly after each planting date. Seedling survival (percentage of surviving seedlings) was recorded every 2 weeks until all seedlings died. The herbaceous foliar cover for each experimental condition was estimated before each planting date. These data were obtained by the canopy-cover method (Daubenmire 1959) with 40 quadrats $(20$ by $50 \mathrm{~cm}$ ) located along 2 transects $(20 \mathrm{~m}$ in length). Herbaceous foliar cover was similar in each experimental area during the study period. Average and standard deviation for the 3 years were: $35 \pm 4.5 \%$ for ungrazed-high cover, $26 \pm 3.8 \%$ for ungrazed-intermediate cover, and $22 \pm 5.6 \%$ for grazed-low cover. After each planting date, and until the end of the seedling survival trials, animals were excluded from the grazed area.

On each sampling date, soil temperature and water potential were measured at a depth of $5 \mathrm{~cm}$ with 5-Spanner thermocouple psychrometers randomly placed on each experimental area. Temperatures were recorded at 0900 hour and 1500 hour and water potential at 1200 hour. Precipitation was recorded at the site with an automatic rain gauge.
Soil temperature and water potential data were analyzed following a completely random design with an analysis of variance and compared by Least Significant Difference test (Snedecor and Cochran 1980). Emergence and seedling survival were analyzed with a generalized linear model (Nelder and Wedderburn 1972) using the REG package (Gilmour 1985). Different grouping of the data on different runs allowed testing the model for the 3-year data set, or for individual years. This was done in view of the poor emergence detected in 1988 as explained in the results section. Contrasts between grazed vs. ungrazed and between intermediate vs. high cover were used to detect differences among treatments.

\section{Results and Discussion}

\section{Germination}

The highest germination percentage of unscarified caldén seeds occurred with a daily cycle of 15 hours of darkness at $15^{\circ} \mathrm{C}$ and 9 hours of light at $30^{\circ} \mathrm{C}$ and at a continuous temperature of $25^{\circ} \mathrm{C}$ under the same photoperiod (Table 1). The lowest germination

\section{Table 1. Germination percentages of unscarified and scarified caldén seeds under 10 different temperature and light regimes. Values followed by the same letter are not signincantly different at $\boldsymbol{P}<0.05$.}

\begin{tabular}{lcc}
\hline \hline Treatments & Unscarified seeds & Scarified seeds \\
\hline & $(\%)$ & $(\%)$ \\
$15^{\circ} \mathrm{C}$ continuous darkness & $8.3 \mathrm{e}$ & $94.2 \mathrm{~g}$ \\
$20^{\circ} \mathrm{C}$ continuous darkness & $29.2 \mathrm{~cd}$ & $100.0 \mathrm{f}$ \\
$25^{\circ} \mathrm{C}$ continuous darkness & $37.5 \mathrm{~b}$ & $98.3 \mathrm{fg}$ \\
$15^{\circ} \mathrm{C}$ with light $(9$ hs daily) & $23.0 \mathrm{~d}$ & $95.0 \mathrm{fg}$ \\
$20^{\circ} \mathrm{C}$ with light (9 hs daily) & $34.2 \mathrm{bc}$ & $97.5 \mathrm{fg}$ \\
$25^{\circ} \mathrm{C}$ with light (9 hs daily) & $46.7 \mathrm{a}$ & $100.0 \mathrm{f}$ \\
$15-25^{\circ} \mathrm{C}$ continuous darkness & $31.7 \mathrm{bc}$ & $98.3 \mathrm{fg}$ \\
$15-30^{\circ} \mathrm{C}$ continuous darkness & $36.7 \mathrm{bc}$ & $100.0 \mathrm{f}$ \\
$15-25^{\circ} \mathrm{C}$ with light (9 hs daily) & $34.2 \mathrm{bc}$ & $99.2 \mathrm{fg}$ \\
$15-30^{\circ} \mathrm{C}$ with light (9 hs daily) & $50.8 \mathrm{a}$ & $99.2 \mathrm{fg}$ \\
\hline
\end{tabular}

percentage was observed at $15^{\circ} \mathrm{C}$ and continuous darkness. Acid scarification significantly increased $(P<0.05)$ germination in all cases. Light seems to have increased germination at the same temperature level for unscarified seeds (Table 1), but differences were not always significant $(P<0.05)$.

Unscarified seeds incubated in light exhibited a lower rate of germination than scarified seeds incubated in light under all temperatures (Table 2). Germination percentages recorded after 72

Table 2. Germination rate of unscarified and scarified caldèn seeds incubated under 5 different temperature regimes with light provided daily for 9 hours. Values followed by the same letter are not significantly different at $P<0.05$.

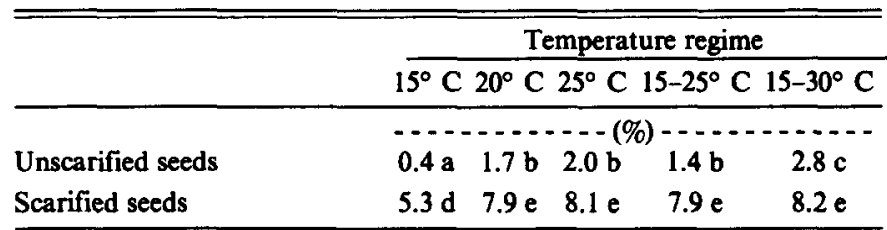

hours of incubation showed the same trend (Table 3 ).

All scarified seeds incubated in light attained $95 \%$ or more germination after the 30-day exposure period (Table 1). However, germination of scarified seeds at a continuous temperature of $15^{\circ}$ C was only $27 \%$ after 72 hours of incubation (Table 3), this delay would explain the relatively low rate of germination for this treatment in Table 2. Scarified seeds of Prosopis chilensis incubated in darkness over the 5 to $45^{\circ} \mathrm{C}$ temperature range, responded in similar way (Mahmoud and El-Sheikh 1978).

Caldén seeds exhibit a degree of dormancy like other members 


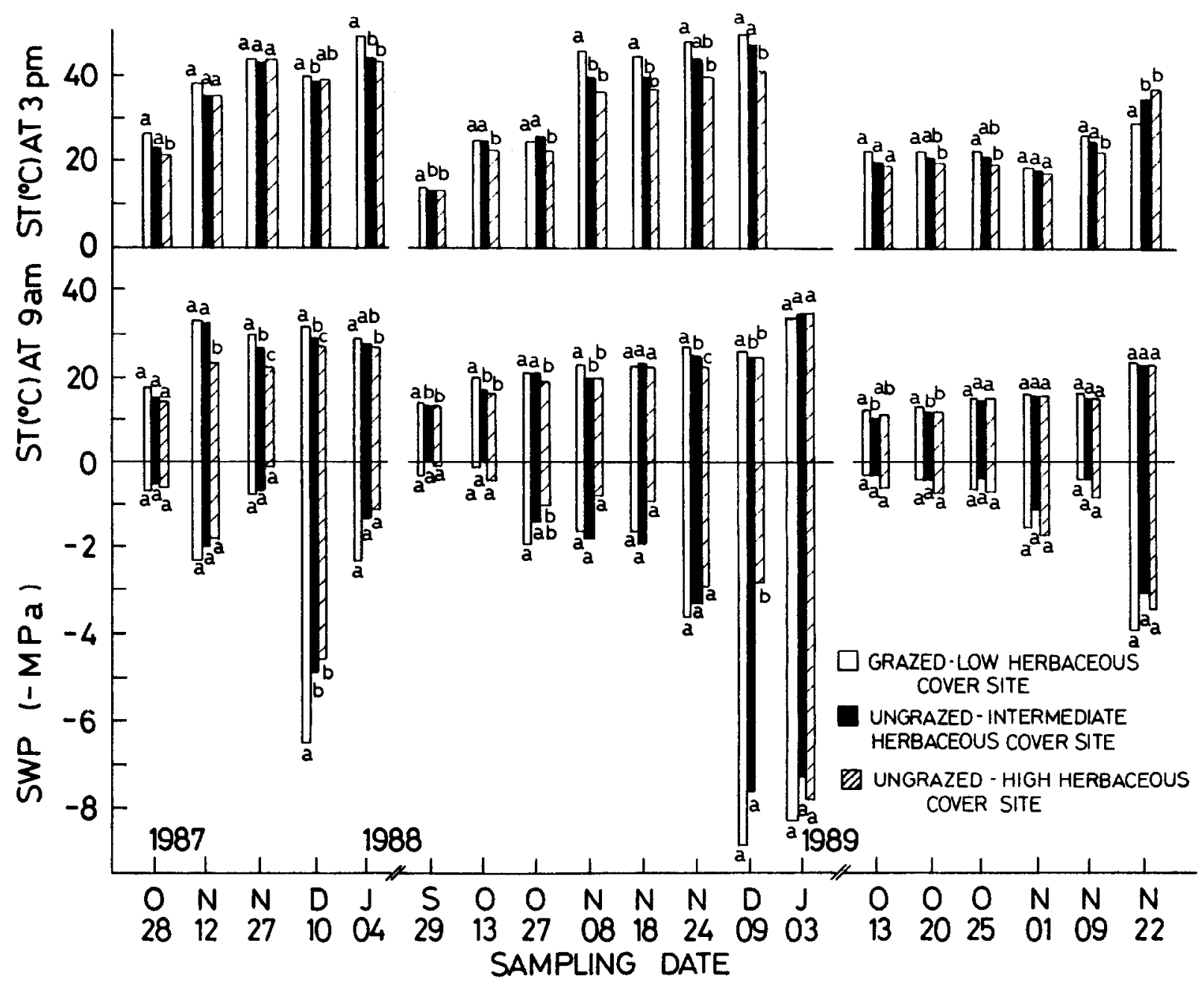

Fig. 1. Soil water potential (SWP) and soil temperature (ST) at $5 \mathrm{~cm}$ of depth in each experimental site. In each sampling date, means with the same letter are not significantly different at $P<0.05$.

Table 3. Germination percentage (G.P.) after 72 hour of incubation of unscarified and scarified caldén seeds incubated at different temperatures with light provided daily for 9 hours.

\begin{tabular}{lcc}
\hline \hline Temperature & Unscarified seeds & Scarified seeds \\
\hline & $(\%) \pm \mathrm{SD}$. & $(\%) \pm \mathrm{SD}$. \\
$15^{\circ} \mathrm{C}$ & 0.0 & $27.0 \pm 6$ \\
$20^{\circ} \mathrm{C}$ & $18.3 \pm 3$ & $93.0 \pm 7$ \\
$25^{\circ} \mathrm{C}$ & $20.0 \pm 6$ & $97.0 \pm 6$ \\
$15-25^{\circ} \mathrm{C}$ & $14.2 \pm 6$ & $90.0 \pm 7$ \\
$15-30^{\circ} \mathrm{C}$ & $21.7 \pm 4$ & $98.0 \pm 4$ \\
\hline
\end{tabular}

of the genus Prosopis (Hass et al. 1973, Mahmoud and El-Sheikh 1978). Dormancy is probably due to the hard seed coat that may restrict water absorption and/or gaseous exchange and was overcome completely by acid scarification. In many seeds dormancy is imposed by the presence of a hard seed coat and their germination depends on altering the seed coat. Their existence permits plants to be distributed in time instead of space which represents an important factor in the continuance of the species (Barton 1965).

Under natural conditions the scarification may take place through passage of seeds through the digestive tract of domestic livestock feeding on the caldén pods, such as was pointed out for mesquite (Hass et al. 1973) and P. chilensis (Mahmoud and ElSheikh 1978). Deposition of seed in manure provides a favorable habitat for germination because of adequate and prolonged mois- ture (Tschirley and Martin 1960). It is common to find many caldén seedlings germinated in the livestock feces and this mechanism of dissemination is likely to encourage spread of caldén when favorable rainfall and temperature occur. Brown and Archer (1988) reported a high density of mesquite seedlings on areas with cattle, in contrast to absence of seedlings on areas without cattle. This suggests that mesquite invasion of grassland would have increased in North America following settlement and introduction of domestic livestock.

\section{Emergence and Survival}

Disturbance caused by grazing produces alterations in the herbaceous cover, amount of litter, micro-relief, soil structure, etc., which changes ecosystem microenvironmental conditions (Harper 1977). However, soil temperatures recorded in the grazed site (Fig. 1) were only occasionally significantly higher $(P<0.05)$ than those recorded in the ungrazed sites. Differences in soil water potential among the different sites were usually not significant $(P<0.05)$. At least in part, the similarity in herbaceous cover, 22 to $35 \%$, among the 3 experimental sites could be responsible for these results.

Annual precipitation and its monthly distribution during 1987 , 1988, and 1989 are given in Table 4. The lowest values of soil water potential were always recorded in late spring and early summer. This was coincident with the highest soil temperatures (Fig. 1).

When emergence data from the 3 years were included in the model(Table5), analysis of deviance showed highly significant differences 
Table 4. Monthly distribution of rainfall (mm) for 1987, 1988, and 1989.

\begin{tabular}{|c|c|c|c|c|c|c|c|c|c|c|c|c|c|}
\hline Year & Jan & Feb & Mar & Apr & May & Jun & Jul & Aug & Sep & Oct & Nov & Dec & TOTAL \\
\hline & - & & & & & & $(\mathrm{mm}$ & & 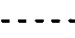 & & $-\cdots$ & --1 & $\ldots$ \\
\hline 1987 & 13.0 & 33.2 & 33.4 & 64.6 & 3.0 & 1.0 & 30.8 & 68.4 & 7.2 & 33.6 & 30.2 & 21.6 & 340.0 \\
\hline 1988 & 3.4 & 19.0 & 103.0 & 24.4 & 12.8 & 6.0 & 10.0 & 17.2 & 58.8 & 19.8 & 5.2 & 20.4 & 300.0 \\
\hline 1989 & 14.6 & 16.0 & 27.0 & 12.0 & 29.0 & 48.0 & 40.8 & 77.0 & 155.0 & 40.0 & 101.2 & 99.6 & 660.2 \\
\hline
\end{tabular}

$(P<0.01)$ for year and treatment, and a significant difference $(P<0.05)$ for the treatment $X$ year interaction. With these data, the highest proportion of the deviance was due to the year factor (83\%). Since emergence was very low for 1988 with 3 replications being 0 , the model was tested considering only data from 1987 and 1989 planting dates. The same results were obtained, but this time the highest proportion of the deviance $(63 \%)$ was due to treatment. Separate analyses were done with data from 1987 and 1989. Results from 1987 data showed a highly significant difference $(P<0.01)$ for treatment. The contrast of grazed vs. ungrazed

Table 5. Emergence percentage recorded after each planting date under grazed-low herbaceous cover (G.L.H.C.), ungraxed-intermediate herbaceous cover (U.I.H.C.), and ungrazed-high herbaceous cover (U.H.H.C.).

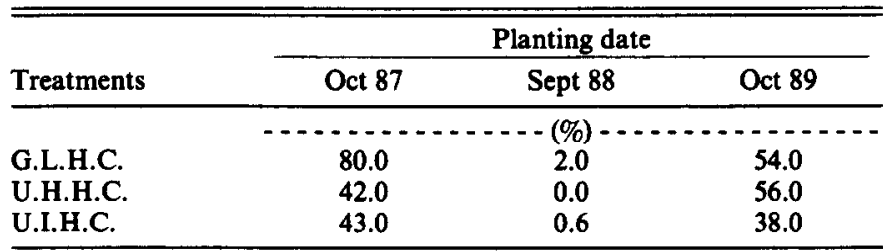

showed that emergence was greater $(P<0.01)$ on the grazed area. Emergence on intermediate vs. high cover within the ungrazed area was similar. A highly significant difference $(P<0.01)$ for treatment was also found for 1989 , but the contrast of grazed vs. ungrazed was not significant and the contrast of low vs. intermediate cover was highly significant $(P<0.01)$. While this may explain the significant interaction (treatment $X$ year) found previously, results may be taken cautiously because there are few data when years are analyzed separately.

In other studies on Prosopis establishment, Smith and Schmutz (1975) and Meyer and Bovey (1982) suggested that herbaceous standing crop or grazing history may have little influence on mesquite establishment. No significant interactions between grazing history and level of defoliation were obtained for either mesquite seedling emergence or survival (Brown and Archer 1989). However, several authors have emphasized the importance of the relationship among grazing, grass biomass, and shrub invasion. Continuous excessive grazing greatly reduced the perennial grass cover and allowed shrubs to increase in the sagebrush/grasslands of western United States (Young et al. 1980). Walker et al. (1981) considered, in their model of savanna stability, the grass biomass as the major factor limiting woody plant encroachment.

Analysis of seedling survival data for the 1987 planting did not show differences $(P<0.05)$ among treatments (Fig. 2). Too few seedlings emerged after the 1988 planting for the survival analysis to be meaningful. Seedling survival was similar among treatments on the first and second evaluation dates after the 1989 planting date (Fig. 3). Results for the rest of the evaluation dates were the same: a significantly greater $(P<0.01)$ seedling survival on the ungrazed area as compared to the grazed area, and no difference within the ungrazed area.

Only a low proportion of caldén seedlings that emerged in ungrazed sites after the October 1989 planting survived for more than 5 months. This coincided with an unusually wet spring-

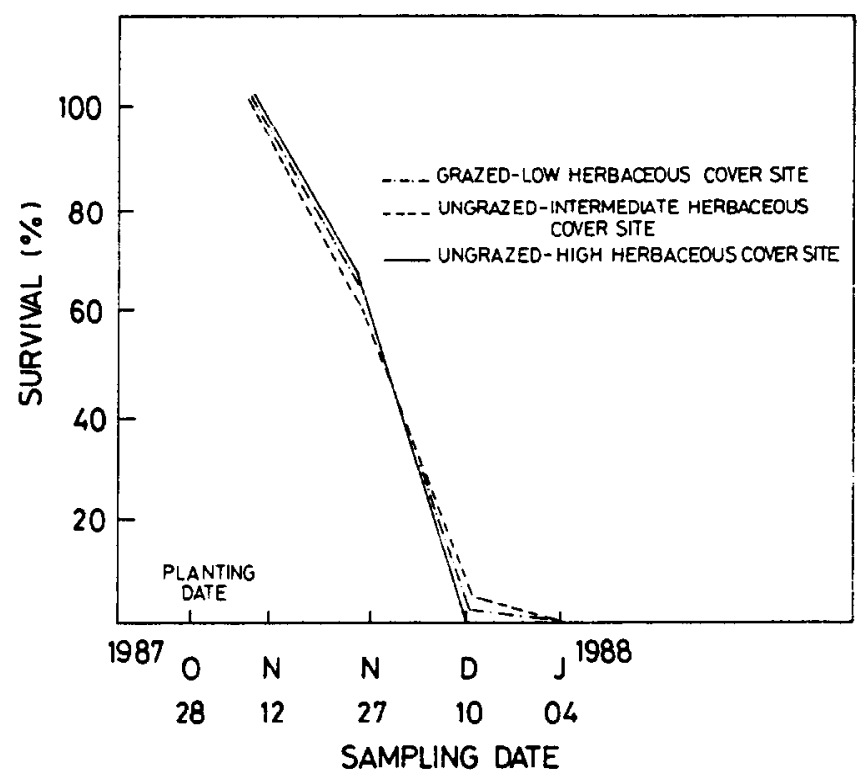

Fig. 2. Caldén seedling survival curves during the period 1987-1988.

summer period for the zone (Table 4). The rest of seedlings that emerged, regardless of herbaceous cover and time period considered, survived 40 days on the average. The highest caldén seedling mortality, regardless of planting date, experimental area and considered period, coincided with higher soil temperature and lower soil water availability. Auld (1987) reported similar results for Acacia suaveolens. Mesquite seedlings did not survive for more than 10 days under a moisture stress higher than 2 atm at $37^{\circ} \mathrm{C}$ (Scifres and Brock 1969). Hodgkinson (1979) pointed out that the proportion of shrub seedlings that establish and survive to reproductive maturity is low, principally due to excessive water stress produced by low rainfall and/or high evapotranspiration rates.

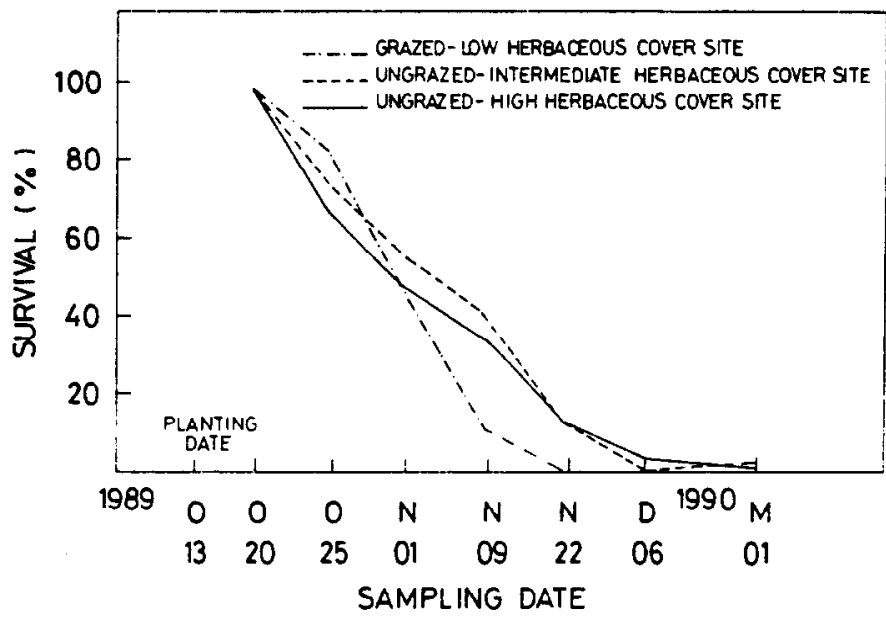

Fig. 3. Caldén seedling survival curves during the period 1989-1990. 
According to Holling (1973) the recruitment pulses are influenced by the co-occurrence of low probability events. Demographic studies (Jordan and Noble 1981, Gutterman 1986) suggest that the recruitment of many woody species, including "woody weeds", from arid and semiarid areas is a rare event. Preece (1971) pointed out that favorable germination events in the field for Acacia aneura could take place as infrequently as once every 9 years.

Percentage herbaceous foliar cover did not consistently affect caldén seedling emergence or survival in the present study. Perhaps the range in percentage herbaceous cover was too narrow to detect a greater effect. Water stress would be the principal cause of seedling mortality. Recruitment of caldén seedlings may occur only in years with above normal and well-distributed rainfall.

\section{Literature Cited}

Auld, T.D. 1987. Population dynamics of the shrub Acacia suaveolens (Sm.) Willd.: Survivorship throughout the life cycle, a synthesis. Aust. J. Ecol. 12:139-151.

Barton, L.V. 1965. Dormancy in seeds imposed by the seed coat, p. 727-746. In: W. Ruhland (ed.). Encyclopedia of plant physiology. Springer-Verlag, Berlin-Heidelberg. N.Y.

Brown, J.R., and S.A. Archer. 1988. Woody plant seed dispersal and gap formation in a North American subtropical savanna woodland: the role of domestic herbivores. Vegetatio 73:73-80.

Brown, J.R., and S.A. Archer. 1989. Woody plant invasion of grasslands: establishment of honey mesquite (Prosopis glandulosa var. glandulosa) on sites differing in herbaceous biomass and grazing history. Oecologia 80:19-26.

Cabrera, A.L. 1976. Regiones fitogeográficas argentinas. Enciclopedia Argentina de Agricultura y Jardinería. Tomo II. Fasc.1. ACME SACI. Buenos Aires.

Distel, R.A., and O.A. Ferníndez. 1987. Leaf water potential trends in three grasses native to semiarid Argentina. J. Range Manage. 40:203-207.

Daubenmire, R. 1959. A canopy-coverage method for vegetational analysis. Northwest. Sci. 33:43-64.

Fowler, N.L. 1988. What is a safe site?: neighbor, litter, germination date, and patch effects. Ecology 69:947-961.

Gilmour, A.R. 1985. REG-A generalized linear model program. Misc. Bull. 1. Dep. Agr. New South Wales, Aust.

Gutterman, Y. 1986. Influences of environmental factors on germination and plant establishment in the Negev desert highlands of Israel, $p$ 441-443. In: P.J. Joss, P.W. Lynch, O.B. Williams (eds.). Rangelands: a rcsource under siege. Aust. Acad. Sci. Canberra, Aust.
Harper, J.L. 1977. Population biology of plants. Academic Press. London.

Hans, R.H., R.E. Meyer, C.J. Scifres, and J.H. Brock. 1973. Growth and development of mesquite, p. 10-19. In: C.J. Scifres (ed.). Texas A\&M University and Texas Agr. Exp. Sta.

Hodgkinson, K.C. 1979. The shrubs of poplar box (Eucalyptus populnea) lands and their biology. Aust. Range. J. 1:280-293.

Holling, C.S. 1973. Resilience and stability of ecological systems. Annu. Rev. Ecol. \& Sys. 4:1-23.

INTA, Provincia de La Pampa, and UN de La Pampa. 1980. Inventario Integrado de los Recursos Naturales de la Provincia de La Pampa. INTA. Buenos Aires.

Jacoby, Jr., P.W. 1986. Control and management of undesirable woody plants on semi-arid rangelands, p. 259-263. In: P.J. Joss, P.W. Lynch, O.B. Williams (eds.). Rangelands: a resource under siege. Aust. Acad. Sci. Canberra, Aust.

Jordan, P.W., and P.S. Noble. 1981. Infrequent establishment of seedlings of Agave deserti (Agavaceae) in the northwest Sonora desert. Amer. J. Bot. 66:1079-1084.

Maguire, J.D. 1962. Speed of germination-aid in selection and evaluation for seedlings emergence and vigor. Crop Sci. 2:176-177.

Mahmoud, A., and A.M. El-Sheikh. 1978. Germination of Prosopis chilensis (Molina) Stuntz. Egypt. J. Bot. 21:69-74.

Meyer, R.E., and R.W. Bovey. 1982. Establishment of honey mesquite and huisache on a native pasture. J. Range Manage. 35:548-550.

Nelder, J.A., and R.W.M. Wedderburn. 1972. Generalized linear model. J. Roy. Stat. Soc. 3:370-384.

Preece, P.B. 1971. Contributions to the biology of mulga. II. Germination. Aust. J. Bot. 19:39-49.

Scifres, C.J., and J.H. Brock. 1969. Moisture-temperature interrelations in germination and early seedling development of mesquite. J. Range Manage. 22:334-337.

Smith, D.A., and E.M. Schmutz. 1975. Vegetative changes on protected versus grazed desert grassland ranges in Arizona. J. Range Manage. 28:453-458.

Snedecor, G.W., and W.G. Cochran. 1980. Statistical methods, 7th Edition. Iowa State Univ. Press, Ames.

Tschirley, F.H., and S.C Martin. 1970. Germination and longevity of velvet mesquite seed in the soil. J. Range Manage. 13:94-97.

Vallentine, J.F. 1974. Range development and improvements. Brigham Young Univ. Press, Provo, Utah.

Walker, B.H., D. Ludwig, C.S. Holling, and R.M. Peterman. 1981. Stability of semi-arid savanna grazing systems. J. Ecol. 69:473-498.

Young, J.A., R.A. Evans, and R.E. Eckert Jr. 1980. Environmental quality and the use of herbicide on Artemisia/Grassland of U.S. intermountain area. Agr. and Environ. 6:53-61. 